\title{
RRI and Patenting: a Study of European Patent Governance
}

\author{
Ellen-Marie Forsberg (D) * Nico Groenendijk
}

Received: 29 April 2018 / Accepted: 3 June 2019 / Published online: 22 July 2019

(C) The Author(s) 2019

\begin{abstract}
This paper addresses the topic of patenting related to the notion of Responsible Research and Innovation (RRI). Focusing on patents in the field of biotechnology, we assess to what extent current patenting practices of the European Patent Organization, and more specifically of its executive body, the European Patent Office (EPO) align with RRI principles. We first argue for including patenting as a relevant topic in the context of RRI and then provide an operationalisation of RRI principles that functions as an analytic tool in the article. We find that the dimensions of RRI currently do not have a strong position in the EPO. Subsequently, we discuss the potential for improving the alignment of the EPO with RRI principles. We conclude the article with some final reflections on the applicability of RRI to the policies and practices of the European Patent Organization.
\end{abstract}

Keywords Responsible research and innovation (RRI) . European Patent Office (EPO) · Patents · Stakeholders · Responsiveness · European patent organization ·

Biotechnology

\author{
E.-M. Forsberg $(\bowtie) \cdot$ N. Groenendijk \\ Work Research Institute, Oslo Metropolitan University, P.O. Box 4 \\ St. Olavs plass, N-0130 Oslo, Norway \\ e-mail: emf@ostfoldforskning.no
}

\author{
N. Groenendijk \\ e-mail: Nico.Groenendijk@ oslomet.no \\ E.-M. Forsberg \\ Ostfold Research, Stadion 4, N-1671 Kråkerøy, Norway
}

\section{Introduction}

Research and innovation provide important goods to society, such as medicines, improved agricultural practices, healthier foods and cleaner energy. When researchers, inventors or companies develop new products or processes, they may file for a patent in order to gain protection of their inventions, in the process of further developing and commercialising them. The reward theory of patents highlights that granting patents to inventors provides an incentive for their research and development efforts [1]. The contract theory argues that inventors are granted patents in exchange for disclosing their invention [2]. On one hand, this arrangement is to the benefit of both individual inventors and society that can build on the knowledge disclosed with the invention, thereby furthering the diffusion of innovation. On the other hand, patents decrease competition by creating temporary monopolies. From this perspective, patent holders may gain more extensive rights than is in the interest of society [3]. Especially combined with restrictive licensing practices patenting may hinder innovation and value creation in general, lead to increased costs of medicines or other goods and lead to taking knowledge out of the public domain and into the domain of private, and often powerful, actors [4].

According to Hall [5], the traditional trade-off in the patent domain between innovation incentives and shortterm monopolies is actually more complicated. The competition effect may be positive as patents may facilitate the vertical disintegration of knowledge-intensive industries. By creating a strong property right, the patent system enables activities that formerly had to be kept 
within the firm because of secrecy and contracting problems to move out into separate and/or new entities. However, the innovation effect can be (partly) offset, as patents tend to increase the costs of subsequent innovators, especially when they need to combine inventions from many sources. The empirical evidence on these possible effects of patenting on innovation and competition is mixed (see inter alia Hall [5], Moser [6]).

While much of the criticism of patent systems is framed from a "logic of consequences" (effects), increasingly patent systems are also being criticized from a "logic of appropriateness" [7], by questioning whether patenting practices are in line with values and norms in society [8]. Important ethical questions can and have been raised, for instance regarding the patentability of certain inventions, especially in the emerging field of biotechnology (see for instance Hettinger [9] or Koepsell [10]). This turns the design and implementation of a patent system into a delicate balancing act, in which various societal concerns have to be taken into account. This article assesses how the European Patent Office, the key player in the European patent system, deals with this balancing act, by means of applying a Responsible Research and Innovation (RRI) framework.

Responsible Research and Innovation (RRI) is a research and innovation strategy that highlights the importance of research and innovation contributing to social goods, not creating undesirable side effects and being developed in dialogue with society and in line with values in society. In the European Commission, there has been a development from addressing RRIrelated issues as 'Science and Society' to 'Science in Society' and to the current concept of 'Science with and for Society'. For the European Commission, 'Responsible Research and Innovation means that societal actors work together during the whole research and innovation process in order to better align both the process and its outcomes, with the values, needs and expectations of European society. RRI is an ambitious challenge for the creation of a Research and Innovation policy driven by the needs of society and engaging all societal actors via inclusive participatory approaches. ${ }^{1}$.

This article is based on a European study ${ }^{2}$ and has thus an explicitly European perspective, focussing on the

\footnotetext{
${ }^{1}$ https://ec.europa.eu/research/swafs/index.cfm?pg=about [accessed April 2019]

2 The Patent Ethics project, https://hioaresponsibleinnovation. wordpress.com/projects/patentethics/, funded by the Research Council of Norway's ELSA program, grant no 220609/O70
}

European Patent Office that operates within the legal framework of the European Patent Convention (EPC). However, the principled questions raised here may also be relevant outside Europe. Drahos [11] documents the initiatives towards more harmonisation of patent law and practices among the EU, the USA and Japan ('the Trilateral Patent Offices'), and RRI-related discussions should be a part of such harmonisation initiatives as well.

Although our interest is in the distributed responsibility of all actors in the patent system for the social impact and societal responsiveness of that system, we here focus on one actor, the European Patent Office (EPO). In the case of the patent system, organisations processing and granting patents (i.e. patent offices) have a particularly great impact on the effects of patenting because they, together with the courts, conduct the de facto interpretation of the intellectual property legislation. Emerging technologies in particular continuously require new judgement in the application of patent legislation because new ground is being broken. The patent offices are important in setting the standards for patenting in these areas, subsequently affecting the patenting strategies of inventors and their attorneys [12]. Moreover, within the European patent system, national European patent offices also process national patents, but largely harmonised with the practices of the EPO. The EPO is therefore the key institution when discussing RRI and patenting in Europe.

The article is structured as follows. First, we discuss how an RRI framework can be used to assess the practices of a patent office such as the EPO ("RRI and its application to patent offices"). In "To what extent is the EPO aligned with RRI principles?", we use four RRI principles to systematically describe relevant aspects of the functioning of the EPO, and to show apparent challenges from an RRI perspective. Subsequently ("How can the EPO align better with RRI principles?"), we discuss the potential for aligning the practices in the EPO better with RRI principles. We will conclude the article with some final reflections on the applicability of RRI to the policies and practices of the European Patent Organization.

\section{RRI and its Application to Patent Offices}

The Relevance of Applying RRI to Patenting Practices

Generally, the RRI literature addresses the responsibilities of researchers for adjusting their research to 
concerns and values in society, in line with, for instance, midstream modulation [13]. No doubt, it is crucial to focus on the responsibilities of researchers and this is in line with decades of research ethics. However, other actors importantly modify the impacts of the actions of individual researchers or research groups. Innovation system approaches (see for instance Lundvall [14]) argue that innovation involves various types of actors. What actors are involved may differ depending on sector [15] or types of technology [16]. Often, the essential actors in innovation systems include research conducting organizations, research funders and other investors, and public authorities (the so-called triple helix, see for instance Etzkowitz and Leydesdorff [17]). Innovation systems may also include other practices or institutions that influence the trajectories and impacts of science and innovation, such as assessment institutions, standardisation organisations and patenting practices [18]. With such influence, these actors also appear relevant to include in an RRI perspective. Challenges of patenting in the RRI perspective lie for example with broad patents hindering downstream pharmaceutical innovation (for instance observed regarding the PD virus in aquaculture), patents on conventional breeding strengthening monopolisation of power in the agricultural sector (a claimed effect of granting patents on conventional tomato, broccoli and salmon) and increased costs of innovation generally because of patent thickets (for instance a threat in gene editing).

Stilgoe et al. [19] confirm the relevance for RRI of a wider perspective on the diverse range of actors in innovation systems. According to these authors, responsible innovation 'demands explicit scrutiny of the tensions and governance mechanisms within processes of research funding, intellectual property regimes and technological standards, which often act to close down innovation in particular ways, and other norms, pressures and expectations that reinforce particular path dependencies and lock-ins'. According to them, this 'de facto governance' [20] is likely to follow what Pellizzoni [21] calls 'a logic of unresponsiveness', in contrast to truly responsible, and responsive, research and innovation (ibid.). However, even if the relevance of patenting in the RRI discourse is acknowledged, there has until now not been conducted a thorough study of RRI and patenting.

How does one 'scrutinise the tensions and governance mechanisms of intellectual property regimes'? In effect, intellectual property regimes are regional and are structured by regional legislation and institutions. The practice of innovators will be dependent on the policies and practices of patent offices as these offices make the decisions on what can be patented. This is what we are mainly interested in in this paper. Innovators' strategies for protection of intellectual property can also be a matter of, for instance, approaches to licensing (see for instance van Overwalle [22]). However, the scope of this paper makes it necessary to focus on the most central locus of the patent system, namely the patent office.

An Analytical Framework for Discussion RRI in European Patenting Practices

Several approaches to RRI exist, most notably von Schomberg [23] and Owen et al. [19], as well as the approach outlined by the EC Expert Group on RRI [24]. René von Schomberg has defined RRI in the following way (2013): 'Responsible Research and Innovation is a transparent, interactive process by which societal actors and innovators become mutually responsive to each other with a view to the (ethical) acceptability, sustainability and societal desirability of the innovation process and its marketable products (in order to allow a proper embedding of scientific and technological advances in our society).'

Owen et al. define responsible innovation as: 'a collective commitment of care for the future through responsive stewardship of science and innovation in the present.' This is a process said to require that innovation be anticipatory, reflective, deliberative and responsive.

The EC Expert Group on RRI defined RRI as: 'Responsible Research and Innovation refers to the comprehensive approach of proceeding in research and innovation in ways that allow all stakeholders that are involved in the processes of research and innovation at an early stage (A) to obtain relevant knowledge on the consequences of the outcomes of their actions and on the range of options open to them and (B) to effectively evaluate both outcomes and options in terms of societal needs and moral values and $(\mathrm{C})$ to use these considerations (under A and B) as functional requirements for design and development of new research, products and services.'

These approaches are also in line with the European Commission's overall RRI philosophy: 'Responsible Research and Innovation means that societal actors work together during the whole research and innovation 
process in order to better align both the process and its outcomes, with the values, needs and expectations of European society. ${ }^{3}$

As can be observed, there are some differences between the approaches and many valid arguments are presented for the different variants. However, rather than arguing for one particular stance towards RRI, we follow here the strategy from Wickson and Forsberg [25] of summarising the different approaches into what is argued to be common in most RRI approaches. According to this approach, for research and innovation to be responsible, it needs to include:

1. A specific focus on addressing significant societal needs and challenges

2. A research and development process that actively engages and responds to a range of stakeholders

3. A concerted effort to anticipate potential problems, identify alternatives and reflect on underlying values

4. A willingness from relevant actors to act and adapt according to $1-3$

These principles capture the essence of RRI and are thus a reasonable framework to apply in an RRI analysis. Below, we discuss to what extent the patenting practices of the EPO are aligned with RRI perspectives, applying the four RRI dimensions presented above.

\section{To What Extent Is the EPO Aligned with RRI Principles?}

Addressing Significant Societal Needs and Challenges

The first RRI dimension states that responsible research and innovation should contribute to solving societal needs and challenges. In an RRI context, addressing such needs and challenges is usually understood more broadly than simply the creation of economic value [23]. Instead, RRI requires more in terms of addressing our times' grand challenges, such as climate change, pandemics or an ageing population, or at least that science and technologies that generate risks or uncertainties are justified by their benefits to society.

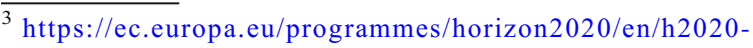
section/responsible-research-innovation. [Accessed April 19th 2019]
}

\section{EPO's Mission}

The EPO describes its mission in the following way: 'As the Patent Office for Europe, we support innovation, competitiveness and economic growth across Europe through a commitment to high quality and efficient services delivered under the European Patent Convention. ${ }^{4}$ Especially in light of the economic crisis that has haunted parts of Europe, this is a mandate with robust societal legitimacy, but it is not fully satisfactory in an RRI perspective. However, in addition to generally contributing to economic welfare, the EPO has engaged in some activities related to addressing grand challenges, namely actions targeting climate change. The EPO cooperated with the United Nations Environment Programme and the International Centre for Trade and Sustainable Development on the program 'Patents and clean energy: bridging the gap between evidence and policy' [26]. ${ }^{5}$ The purpose has been to provide 'reliable evidence' as intellectual property rights in the field of climate change technologies have been regarded as 'a particularly contentious issue' [26, p. 6]. The EPO also organizes the European Inventor Award, which provides an award to an 'exceptional contribution to social development, technological progress and economic growth ${ }^{6}$ and has a certain profile towards environmental and climate technologies. ${ }^{7}$

\section{Patenting Practices}

In an RRI perspective, this is relevant, but more interesting is the question of how societal needs are reflected in the core activities, which, in the case of patent offices, means the level of processing patent applications. On this level, the EPO explicitly distances itself from a connection to any positive impacts other than the general macroeconomic assumption that patenting creates economic value and innovation. EPO Guideline G.I.3 states: 'The EPC does not require explicitly or implicitly that an invention, to be patentable, must entail some

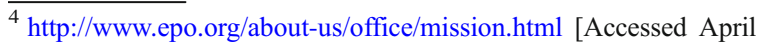
2019]

${ }^{5}$ Regional follow-up reports for Africa, Latin America and Europe have subsequently been produced by the EPO and UNEP, see http://www.epo.org/news-issues/technology/sustainabletechnologies/clean-energy.html [Accessed April 2019]

${ }^{6} \mathrm{http} / / / \mathrm{www}$.epo.org/learning-events/european-inventor/press.html [Accessed April 2019]

${ }^{7} \mathrm{http}: / / \mathrm{www}$.epo.org/news-issues/technology/sustainabletechnologies.html [Accessed April 2019]
} 
technical progress or even any useful effect.' ${ }^{8}$ EPO Guideline G.II.4.1.3 adds: 'The EPO has not been vested with the task of taking into account the economic effects of the grant of patents in specific areas of technology and of restricting the field of patentable subjectmatter accordingly. ${ }^{9}$ These guidelines echo the position that a patent is not a positive right to exercise the invention (as there may be other legislation regulating or even prohibiting the actual use of the invention), but a negative right, i.e. a right for an inventor to prevent other actors to exploit his/her invention, for a certain period. ${ }^{10}$ Patent scholars have therefore maintained that assessing the benefits of assumed use of individual patents is not relevant and patent offices are not equipped to take on such a task [27, 28]. Thus, questions related to the impacts (positive or negative) of an invention have no place in the patent system.

One article in the EPC does, however, address the impacts of a patent, namely the article describing the exceptions to patentability (article 53 EPC). Article 53(a) EPC shows that in special cases, a patent may be refused and these cases are related to certain technologies that are seen as inherently controversial: namely 'inventions the commercial exploitation of which would be contrary to "ordre public" or morality'. The article explains that 'such exploitation shall not be deemed to be so contrary merely because it is prohibited by law or regulation in some or all of the Contracting States'. The EPO guidelines for examination say about article 53(a) EPC: 'The purpose of this is to deny protection to inventions likely to induce riot or public disorder, or to lead to criminal or other generally offensive behaviour [...] This provision is likely to be invoked only in rare and extreme cases. ${ }^{11}$ Article 53(a) EPC thus does not request any ethical impact assessment but simply gives the EPO a possibility to deny extremely controversial patents. In the Relaxin/Howard Flory Institute case (T0272/95, 1995), the EPO had to decide whether human genetic material was patentable or not. The Opposition Division argued that a 'fair test' under article 53(a) would be to consider whether it is probable that the

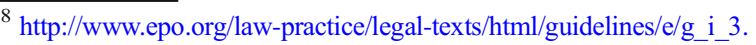
htm [Accessed April 2019]

${ }^{9} \mathrm{https}: / / \mathrm{www}$.epo.org/law-practice/legal-texts/html/guidelines/e/g_ ii_4_1_3.htm [Accessed April 2019]

${ }^{10}$ See for instance point 18.2 of the EPO Board of Appeal Decision in case T 356/93.

${ }^{11} \mathrm{http}: / /$ www.epo.org/law-practice/legal-texts/html/guidelines/e/g_ ii_4_1.htm [Accessed April 2019]
}

public in general would regard the invention as so abhorrent that the grant of patent rights would be inconceivable. In this case, where the DNA sequence, which codified the hormone relaxin, was taken from pregnant women and then used in industrial production of the hormone, the Opposition Division (later supported by the Board of Appeal) saw no grounds to reject the patent based on this test. The 'fair test' was later incorporated into the EPO Guidelines on article 53(a).

However, a few years earlier, in the decision of the Board of Appeal in the case of the Onco-mouse/Harvard (T19/90, 1990), another test, the so-called Harvard test, was formulated. In this case of a mouse genetically modified for developing cancer, the Board of Appeal held that article 53(a) EPC should be applied by 'a careful weighing up of the suffering of animals and possible risks to the environment on the one hand, and the invention's usefulness to mankind on the other'. This test, relevant to patent applications where it is clear that the patented animal suffers, requires taking into account the benefits to society of the invention.

As from September 1999, article 53(a) EPC has been supplemented by a rule covering only the biotechnology context, offering additional advice on how to interpret this article in this context. This rule also opens for a certain consideration of benefits of inventions. Based on article 6 of the EU Directive on the legal protection of biotechnological inventions (98/44/EC; hereafter: Biotech Directive), rule 28(1) of the Implementing Regulations to the Convention on the Grant of European Patents specifies that

European patents shall not be granted in respect of biotechnological inventions which, in particular, concern the following:

(a) processes for cloning human beings;

(b) processes for modifying the germ line genetic identity of human beings;

(c) uses of human embryos for industrial or commercial purposes;

(d) processes for modifying the genetic identity of animals which are likely to cause them suffering without any substantial medical benefit to man or animal, and also animals resulting from such processes.

Letter (d) shows that in the specific case of inventions that modify the genetic identity of animals (and animals resulting from such processes) and 
where this modification likely causes suffering, there must be an assessment of benefits to society. These should be substantial but are limited to the medical domain. In contrast to article 53(a) EPC, only animal suffering should be balanced here (i.e. not environmental risks). So how does the EPO perform this balancing act?

In a Board of Appeal decision on another case of transgenic animals (T315/03 Transgenic animals/Harvard, 2006), the Board judged (based on expert statements submitted by the applicant) that substantial medical benefit was provided by a transgenic mouse, but that no evidence had been submitted to prove that other similarly modified mammals would have a similar benefit. Consequently, the Board decided that the patent could only be granted on the mouse.

In the case of Non-invasive localization/Leland Stanford (T1262/04, 2012), the Board of Appeal made a similar judgement on benefit: they referred to three expert statements presented by the inventor that underscored the medical benefits of the invention. The Board then stated: 'In view of the above, the board concludes that the claimed methods of the invention are at least likely to be of substantial medical benefit to man, thus fulfilling the criterion provided for in rule 28(d) EPC for escaping the patent exclusion. Likewise, when applying the balancing test as developed in T19/90 (supra), the board considers that this likelihood of substantial medical benefit demonstrates the invention's usefulness to mankind in human cancer research. The board notes in addition that the appellant's credible assertion that the claimed methods lead to a reduction of the number of experimental animals in cancer research is a further relevant factor in this balancing exercise.' The Board consequently remitted the case to the department of first instance with the order to grant a patent.

The European patent EP1330552, on selection for the breeding of dairy cows by marker DNA, was granted in 2007 (it was revoked in 2015 by EPO, because of non-compliance of the patent-holder with administrative requirements). The patent was opposed and appealed by Greenpeace related to several provisions in the EPC, including rule $28(\mathrm{~d})$. The opposition and appeal procedures showed that there were strict requirements on Greenpeace to document that the animals suffered. Greenpeace did not have documentation related to the specifics of the case, as studies had not been published on this particular modification. The EPO thus did not find the objections justified and subsequently stated that there was no need to document any benefits to offset the nondocumented suffering.

Based on these cases, it seems that in the domain of biotechnological inventions, the EPO accepts suffering of animals if the invention is at least likely to be of substantial medical benefit to man. If suffering is not sufficiently documented, there is no need to document the benefits. In its T1262/04 decision (and referring to $\mathrm{T} 315 / 03$ ), the Board pointed out that rule 28(d) does not prevent objection based on article 53(a) EPC. This means that even if the application passes the balancing test of rule $28(\mathrm{~d})$, objections can still invoke the more general Harvard test, or the Relaxin 'fair test'.

Overall, in its patent granting processes, the EPO takes benefits of patents to society into account only in a very limited number of specific cases, i.e. where rule 28 and/or article 53 EPC apply and suffering/harm has been documented. Case law shows that documenting such harm is not straightforward.

\section{Engaging with Stakeholders}

Engaging with stakeholders is important in all approaches to RRI. How does the EPO itself define the scope of its stakeholders? According to the EPO, it has many stakeholders, which are listed as 'staff, users, member states, and the wider public, among other groups'. ${ }^{12}$ This signals a broad approach to inclusion of stakeholders, in line with RRI principles. In this section, we will therefore follow EPO's distinction between these four stakeholder groups.

Stakeholder engagement in European patenting can be addressed on two levels: the institutional level and the level of the patent granting process. The institutional level is relevant to discuss here because it may affect patent granting practices and will be discussed first.

\footnotetext{
$\overline{12}$ See p. 3 of the draft Strategic Plan 2023, issued in April 2019. (http://documents.epo.org/projects/babylon/eponot.nsf/0/931F1C2A8 C94B16EC125838B004725D4/\$FILE/EPO_Strategic_Plan_2023_ draft_en.pdf [Accessed April 2019]). This plan, drafted under the presidency of António Campinos, and the accompanying consultation round, addresses the central issue of how the EPO and its work can be organized in order to balance the needs of its many stakeholders.
} 
Engagement with Stakeholders at the Institutional Level

Engagement with Member States and Users We will first focus on the engagement of the EPO with member states and with users/clients.

The EPO is the executive office of the European Patent Organisation, an intergovernmental organisation that further consists of the Administrative Council (hereafter: AC). According to article 4(3) EPC, the AC acts as the EPO's supervisory body. The AC is composed of representatives of the 38 member states of the European Patent Organization. They are commonly represented by (the heads of) their national patent offices. Additionally, the European Patent Organisation involves two extension states (Bosnia and Herzegovina, and Montenegro) and four validation states (Moldova, Morocco, Tunisia and Cambodia). These states have an observer status in the AC; the same is true for the EU, the World Intellectual Property Organization (WIPO), the European Union Intellectual Property Office (EUIPO), the Nordic Patent Institute (NPI), BUSINESSEUROPE and the Institute of Professional Representatives before the European Patent Office (epi). The EPO President participates in the AC meetings, as do representatives from the Board of Auditors and the EPO Staff Committee (in which EPO staff is represented). ${ }^{13}$ The AC operates two bodies (which confusingly are called committees: the Technical and Operational Support Committee and the Committee on Patent Law), as well as two committees (the Budget \& Finance Committee, and the Select Committee). These bodies/committees have similar compositions as the AC.

In 1992, the EPO European Roundtable on Patent Practice (EUROTAB) was established as a mechanism for national offices in the EPC contracting states and the EPO to exchange views and compare approaches on matters of a practical nature concerning the patent grant procedure, both from a substantive and formal point of view. BUSINESSEUROPE, epi and the International Federation of Inventor's Associations (IFIA) are also invited to this Roundtable. Earlier, in 1978, the EPO

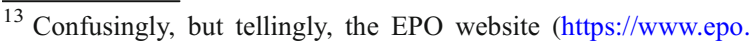
org/about-us/organisation/administrative-council/composition.html [Accessed April 2019]) lists the member states representatives, the EPO president, the members of the Board of Auditors, as well as the members of the Staff Committee all as 'participants' of the AC. Articles 26-30 EPC are however clear: only the member states' representatives are members; the EPO president takes part in the deliberations, and the meetings can be attended by observers.
}

Standing Advisory Committee before the European Patent Office (SACEPO) was established 'in order to give "interested circles" a say in the development of the European patent system'. ${ }^{14}$ Membership is comprised of representatives from industry (nominated by BUSINESSEUROPE) and the patent profession (nominated by epi), as well as some recognised experts in the field of industrial property law appointed ad personam by the EPO President. Regular meetings are held once per year in Munich and extraordinary meetings and written consultations are also organised whenever an issue of particular importance arises.

Engagement of the EPO with the member states/ national patent offices and with its users/clients is thus very well established. The entanglement of national patent offices, EPO, BUSINESSEUROPE and epi, confirms that most patent offices regard the inventors seeking patents as their 'clients' or 'users' (see Schneider [29], Borras [30] and Drahos [11]) and that the inventors ${ }^{15}$ have a privileged place in the patent system, both in the national patent systems and in the EPO. This is confirmed by EPO:

Representatives of the legal profession and industry have always had observer status in the Administrative Council of the European Patent Organisation, something which is exceptional for an international organisation. This means that users' views are heard before legislative, budgetary and technical matters are decided by the Organisation's member states. [...] This approach has facilitated an open and informed debate and has contributed significantly to the development of the European patent system. ${ }^{16}$

On a normative note, given this entanglement, one can however question the way that the EPO and the European Patent Organisation at large deal with the proper division of responsibilities and with governance issues. There hardly seems to be a proper supervisor-supervisee relationship within the European Patent Organisation. The supervisory body (AC) is made up of representatives of national patent offices, which cooperate

\footnotetext{
$\overline{14}$ http://www.epo.org/about-us/office/sacepo.html [Accessed April 2019]

${ }^{15}$ Drahos [11] shows that among the inventors multinational corporations are clearly the largest group.

$16 \mathrm{http}: / /$ www.epo.org/about-us/office/quality/Consultingourusers. html [Accessed April 2019]
} 
intensively with the EPO. It is common to elect the EPO President from within the circles of heads of national patent offices. The main exception was Alain Pompidou (EPO President from 2004 to 2007), who was a scientist and politician, without any background in the patent system. The current EPO President, António Campinos, has been executive director of the EUIPO from 2010 to 2018, but before 2010 was head of the Portuguese national patent office (and thus member of the AC). The confusing and blurred use of the acronym EPO (on the website, in documents) for both the European Patent Organization and the European Patent Office does not help to properly demarcate responsibilities.

Another question is whether BUSINESSEUROPE and epi cover the full range of interests from their sectors. BUSINESSEUROPE, the European association of national business associations, also plays an important role as stakeholder in EU decision-making, but in that arena, it is contested for having a de facto privileged status, with early access to institutions such as the European Commission. ${ }^{17}$ Recently, it has been criticised from within the larger European business community for its restrictive position on measures to deal with climate change. ${ }^{18}$ epi consists of European patent attorneys with special qualifications (as outlined in article 134-8(b) EPC), who are registered by the EPO; membership of epi is mandatory for registration as a European patent attorney. Overall, the entanglement of the EPO, the AC/national patent offices, BUSINESSEUROPE and epi seems to have many characteristics of a 'closed shop'.

Engagement with the Wider Public In contrast, stakeholders that are not considered as users do not have a designated place in the institutional set-up of the European patent system. The coordinator of one of the most important non-industrial stakeholders in the European patent system, the platform of NGOs called No Patents on Seeds! says the following about how the European patent system can be made more responsive to concerns

\footnotetext{
$\overline{17}$ See EUObserver, 24 June 2015 (https://euobserver. com/justice/129259) [Accessed April 2019] and Transparency International's website on EU lobbying: http://www.integritywatch.eu [Accessed April 2019]. According to some NGOs BUSINESSEUROPE heavily understates its lobby-related expenditure, which it had to disclose upon registration in the EU Transparency register, see https://corporateeurope.org/blog/businesseurope-smallfish-lobbying-pond [Accessed April 2019].

${ }^{18} \mathrm{See}$ https://www.euractiv.com/section/climateenvironment/news/leaked-memo-exposes-business-rift-on-climatechange/ [Accessed April 2019].
}

represented by a broader group of stakeholders: 'The list is long... We do not have an independent court, we do not have any relevant participation of civil society organizations, and we do not have fora for participation. Political governance (such as in the Administrative Council) is performed by people close to the patent world. Everything is missing. Nothing will ensure that civil society has access. ${ }^{, 19}$

From 2012 to 2015, the EPO had an Economic and Scientific Advisory Board (ESAB). This board consisted of 11 independent academic experts and practitioners, supported and coordinated by the EPO Chief Economist. Although the ESAB published various relevant reports, it was decided not to continue its activities. One of the few stakeholder events organised by the EPO and documented in the literature appears to be a workshop on the interaction between the EPO and civil society (in 2009, see Parthasarthy and Walker [31, p. 339]). More recently, in May 2018, the EPO organised a conference on patenting and artificial intelligence ${ }^{20}$, aiming at connecting people from business, academia, the judiciary, policymaking and patent offices. The conference included a session on ethical and social considerations.

Overall, EPO's engagement with a wider audience (civil society, the public at large) thus seems to be very limited.

Engagement with EPO Staff Another important stakeholder of the EPO is the Staff Union of the European Patent Office (SUEPO). SUEPO represents the interests of EPO staff in general and those of its members in particular; approximately $50 \%$ of EPO staff is members of SUEPO. SUEPO takes particular care to maintain acceptable working conditions for the staff of the EPO. This concerns not only remuneration but also a wide range of everyday aspects of working conditions at the EPO, such as working time, working pressure and ergonomics. SUEPO also claims to represent wider public interests because ' $[\ldots]$ patenting is a complex issue and citizens must be better informed of the functioning and the relevance of patents'. ${ }^{21}$

EPO's engagement with SUEPO is problematic, to say the least. Labour relations were largely normal under

\footnotetext{
${ }^{19}$ Information by Christoph Then, coordinator of No Patents on Seeds! in a telephone interview August 2015.

${ }^{20} \mathrm{https} / / / \mathrm{www}$. epo.org/learning-events/events/conferences/2018 /ai2018.html [Accessed April 2019].

${ }^{21} \mathrm{http} / / /$ www.suepo.org/public/about [Accessed April 2019].
} 
the Pompidou (2004-2007) and Brimelow (2007-2010) presidencies, even though SUEPO already in 2009 stated that 'the social climate within the Office has degraded to a level that can only be described as catastrophic' [32, p. 5]. This situation further deteriorated under the presidency of Benoît Battistelli (2010-2018). An overview of all conflicts since 2010 is beyond the scope of this paper. They are extensively documented on SUEPO's website, but of course from their perspective. They include the lack of formal recognition of SUEPO by $\mathrm{EPO},{ }^{22}$ dismissal and downgrading of several SUEPO leaders, various other controversial disciplinary proceedings and contested reforms of the EPO career system. These conflicts led to many demonstrations by EPO staff in Munich, starting in December 2014, with the latest in March 2018.

Two institutional factors seem to have contributed to the persistent bad labour relations at EPO, in addition to the management style of Battistelli and his continuous drive for efficiency. First, whereas the employment conditions and rights of civil servants in national public organisations are laid down in national regulations, with national courts having jurisdiction in the case of labour conflicts, the European Patent Organisation, as an international organisation, is not bound by any national labour legislation and does not fall under the jurisdiction of national courts (immunity). ${ }^{23}$ Rules and rights regarding employment have been laid down in an internal codex of Service Regulations, ${ }^{24}$ adopted by the AC, upon recommendations of the EPO President. This means that the EPO, as an employer, can unilaterally determine employment conditions and employee rights. Secondly, based on article 13 EPC, the Administrative Tribunal (AT) of the International Labour Organisation (ILO) is the external instance for resolving individual labour conflicts, but this external procedure is lengthy and deals with individual cases only (not with collective

\footnotetext{
${ }^{22}$ In 2016, the EPO did sign a memorandum of understanding (MoU) with the Fédération de la fonction publique européenne, European Patent Office, The Hague (FFPE-EPO), another trade union for EPO staff, established in 2008. This EPO-approved union has never really taken off and represents a very limited number of staff members (less than $1 \%$ ).

${ }^{23}$ In a case concerning EPO staff in The Hague, initially, in 2015, a Dutch lower court (Gerechtshof) ruled that the EPO was violating the European Treaty on Human Rights by blocking mails from the labour unions and by limiting the workers' right to strike. This decision was however overturned by the Dutch Supreme Court (Hoge Raad) in January 2017, which confirmed EPO's immunity.

${ }^{24}$ See https://www.epo.org/about-us/office/service-regulations.html [Accessed April 2019].
}

rights such as the right to strike, or general problems such as excessive workload). In the case of dismissal or downgrading of three EPO staff members, originating from late 2015/early 2016, the ILO ruled in June 2018 that the EPO's disciplinary measures should be fully reversed. ${ }^{25}$

What has the EPO done to improve labour relations, given the high level of conflict? In February 2016, the Board of the AC put pressure on EPO President Battistelli. In a confidential meeting ${ }^{26}$ between the Board and the EPO President, the Board 'deplored an obvious lack of willingness from the part of the President to embark on an overdue open discussion with the Council on contentious issues - foremost the social dialogue', with the President disagreeing. Still, this interference and the subsequent AC Resolution of March 2016 urging the EPO President to inter alia reform the disciplinary sanction system at $\mathrm{EPO},{ }^{27}$ triggered a process, which, in October 2016, resulted in the 'first ${ }^{28}$ EPO Social Conference. This conference took place in Munich, and during the conference (preliminary drafts) of three recent studies into the EPO's social and financial situation were discussed, as well as occupational health and working conditions. ${ }^{29}$ The relevance of this Social Conference was however perceived differently by EPO than by some stakeholders, such as SUEPO, which was not invited to participate. Various items on the SUEPO website, as well as another demonstration by EPO staff in Munich in December 2016 and subsequent demonstrations in 2017 and 2018, indicate that the relationship between SUEPO and EPO has not significantly improved as a result of this conference mechanism.

The new EPO President, Campinos, in his letter of motivation for applying for the presidency, ${ }^{30}$ identified the increase of staff engagement at EPO as one of his

\footnotetext{
${ }^{25}$ ILOAT rulings 4042, 4043 and 4047 of June 2018.

${ }^{26}$ The minutes of which can be found at http://techrights.org/2016/03 /09/text-of-the-conclusions-of-the-b28-meeting/ [Accessed April 2019].

${ }^{27}$ AC resolution $\mathrm{CA} / 26 / 16$ of 17.03 .2016 .

28 To date, there have been no subsequent social conferences at EPO.

${ }^{29}$ The three studies, which are not publicly available, were commissioned by the EPO to PricewaterhouseCoopers, Deloitte, and the International Institute of Risk and Safety Management. Especially the $\mathrm{PwC}$ report was criticized heavily for misrepresentation of the situation at EPO, for example by the EPO Central Staff Committee (see http://techrights.org/wp-content/uploads/2016/10/sc16188cp.pdf [Accessed April 2019]).

${ }^{30} \mathrm{https} / / / \mathrm{blog}$.epo.org/wp-content/uploads/Letter-of-Motivationvs0.1.pdf [Accessed April 2019].
} 
main challenges. The relevance of that challenge is also shown by the outcomes of an EPO Staff Engagement Survey of March 2019, which among other things showed that only $16 \%$ of EPO staff has confidence in EPO senior management. ${ }^{31}$ The survey has been used as input for the recent draft Strategic Plan of April 2019, which lists the fostering of the social dialogue at EPO as one (of the overall 32) key initiatives. This includes reengagement of the EPO with the unions with the aim to formalise recognition and measures to ensure the responsible use of the internal system of justice.

To conclude this subsection, the observations suggest that, with the exception of the engagement with national patent offices, businesses and patent attorneys, the institutional stakeholder engagement with, and the involvement of citizens by, the EPO is currently at a very low level.

\section{Engagement with Stakeholders at the Patent Processing Level}

There are stakeholders and interested parties not only at the institutional level, concerning the EPO in general, but also in many cases of specific patents, and these may interact with the EPO in three different ways.

First, any member of the public can intervene in a patent granting process by filing a third-party observation about the patentability of the invention (art. 115 EPC). No fees are required for the submission of such an observation. Basically, this provides a mechanism by which prior art otherwise undisclosed to the EPO examiners is included in the examination, but as article 115 EPC uses the term 'patentability', third-party observations have a broader potential and are not necessarily limited to the issue of novelty. Third-party observations are also communicated to the applicant. The possibility of (pre-grant) third-party observations is used rather infrequently, compared to the number of (post-grant) oppositions and appeals [33]. This may be due to the fact that competitors are not inclined to forewarn the applicant of prior art and will wait until the patent is granted, after which they file an opposition (ibid.). Another reason may be the fact that, in line with the Guidelines, ${ }^{32}$ EPO does not communicate to third

\footnotetext{
$\overline{31}$ http://patentblog.kluweriplaw.com/2019/04/07/epo-staff-surveyconcerns-about-quality-low-confidence-in-management-lack-ofrespect/ [Accessed April 2019].

$32 \mathrm{https} / / /$ www.epo.org/law-practice/legal-texts/html/guidelines/e/e vi_3.htm [Accessed April 2019]
}

parties about what is done with their observations [34]. Kica et al. [35] however show that in the area of human gene patents (where patentability is highly controversial) some particular patent cases evoked a very large number of third-party observations. For example, in the BRCA1 case (EP0705902) on a breast cancer gene, various NGOs, academic societies and research institutes, as well as patient organisations together submitted 150 observations (see also [36]).

Second, any member of the public can file an opposition within 9 months of the EPO's mention that a patent has been granted (article 99 EPC). If the patent is maintained after an opposition, the complainant can file an appeal within 2 months of the decision (articles 106-108 EPC). If so, the appeal can be assessed in a Technical Board of Appeal or referred to an Enlarged Board of Appeal for more principled cases. Patents are generally opposed by competitors. ${ }^{33}$ Several characteristics of the patent system function as barriers hindering the involvement of other stakeholders:

- It is hard to keep updated on relevant new patents filed for examination. Although these are public, finding the information on EPO's web service or via the EPO Bulletin often requires expert knowledge. There are also patent database search services, but these require subscription;

- If a patent application of societal interest is found, it may (especially in the fields of emerging science and technologies) be written in a very technical language, making it difficult for stakeholders that are not themselves experts in the field of the patent application at hand to understand the content of the claims

- For oppositions and appeals, there is a fee (currently $€ 785$ for an opposition, and $€ 1880$ for an appeal), which may prohibit less resourceful and nonorganised interested parties to intervene

- Engaging in opposition and appeal requires quite substantial resources, as these procedures will be a matter of interpreting legal texts, requiring legal expertise in addition to the technological expertise

The barriers for engaging in such dialogues are therefore prohibitively high for most non-industrial stakeholders. In spite of these barriers, there are examples of non-industrial stakeholders engaging in opposition

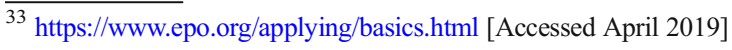


and appeal cases. For example, No Patents on Seeds! (in which several NGOs such as Greenpeace cooperate) has been very active in disputing patent cases in the field of biotechnology (especially patents on plants and animals). ${ }^{34}$ No Patents on Seed!'s experience is that 'it is difficult for civil society organizations to engage in or have an impact in appeal or court procedures, because this usually requires engaging a lawyer, which is expensive for civil society organizations, ${ }^{35}$

Third, in order to ensure uniform application of the law, or if a point of law of fundamental importance arises, the Boards of Appeal can refer a case to the Enlarged Board of Appeal (article 112(1)(a) EPC). Similarly, the President of the EPO may refer a point of law to the Enlarged Board of Appeal where two Boards of Appeal have given different decisions on that question (article 112(1)(c) EPC). Under article 112 EPC proceedings, third parties can issue written statements concerning the points of law raised in such proceedings (article 10(1) Rules of Procedure of the Enlarged Board of Appeal). Such statements of third parties are known as amicus curiae briefs. The Enlarged Board also has the possibility to explicitly issue requests and to provide further provisions concerning such briefs. The way that the Enlarged Board of Appeal uses these third-party statements has developed over the years. As from 1999, third-party statements were made in seven referral cases involving patents in the field of biotechnology. ${ }^{36}$ In two early cases (G1/98 and G1/04), in which thirdparty statements were not invited, the number of such statements was limited, and the Enlarged Board of Appeal, in its rulings, gave relatively extended overviews of these statements. In all other cases, third-party statements were invited, and they were made in such large numbers that the Enlarged Board of Appeal appears to be able to deal with them only in a very limited manner. Statements are grouped according to being pro or contra patentability, and in some (but not all) cases, this is

\footnotetext{
${ }^{34}$ See for an overview of the most important cases: http://no-patentson-seeds.org/en/patent-cases [Accessed April 2019].

35 Information by Christoph Then, coordinator of No Patents on Seeds! in a telephone interview August 2015.

${ }^{36}$ See https://www.epo.org/law-practice/case-lawappeals/eba/number.html [Accessed April 2019] for the full list of Enlarged Board of Appeal Decisions under article 112 EPC. The biotech cases referred to here are G1/98 (Transgenic Plant/NOVARTIS II), G1/04 (Diagnostic methods), G2/06 (Use of embryos/WARF), G2/07 and G1/08 (Essentially biological processes), G2/08 (Dosage regime/ABBOTT RESPIRATORY), G2/12 (Tomatoes II) and G2/13 (Broccoli II). The most recent case (G3/19: Pepper, a case referred by the EPO president on April 4, 2019) is still pending.
}

followed by a very brief overview of the common denominator of their contents. For example, in G2/06 (Use of embryos/WARF; 2008), the Enlarged Board of Appeal received numerous statements regarding the moral unacceptability of this patent. A considerable number of these were identical, only with different signatures, and appear to be the result of a campaign. Even though Sterckx and Cockbain [37, pp. 286-287] argue that the EPO in this case changed their approach to ethics, from a purely utilitarian approach to considering deontological arguments, the text of the decision does not demonstrate that the (large number of) amicus curiae briefs influenced the EPO considerations.

Generally, statements by third parties in article 112 proceedings may be dealt with as the Enlarged Board sees fit (article 10(2) Rules of Procedure of the Enlarged Board of Appeal). In cases G2/12 (Tomatoes II; 2015) and G2/13 (Broccoli II; 2015), which were dealt with together, the Enlarged Board of Appeal acknowledged the receipt of a large number of third-party statements expressing general objections against patenting the kind of technologies at issue, based upon ethical, economic and social concerns (G2/12, p. 29). But it emphasised (p. 56) that the issues referred to the board relate to questions of law, rather than to economic, social or ethical aspects brought up in some of these amicus curiae letters. In other words, the scope of the input from stakeholders (other than involved parties from industry) and from the public that is seriously considered by EPO is currently very narrow.

Anticipating Potential Problems, Identifying Alternatives and Reflecting on Underlying Values

RRI scholars, such as Stilgoe et al. [19], highlight the need for reflexivity and reflection on values, options and impacts in the research and innovation process. The assumption is that there are values and uncertainties embedded throughout the research and innovation process, and these should be openly discussed. Here, we explore the extent of such open reflection and reflexivity, first at the EPO institutional level and then at the level of the granting of patents.

\section{Reflexivity at the Institutional Level}

In the period 2004-2007, under the presidency of Alain Pompidou, the EPO engaged in a scenario process: Scenarios for the Future [38]. Here, more than 100 experts and stakeholders of the patent system were 
interviewed about their views on challenges and opportunities facing EPO and the European patent system in general. This resulted in four scenarios (with four different dominant drivers): Market Rules (business), Whose Game? (geopolitics), Trees of Knowledge (society) and Blue Skies (technology). The EPO says:

The purpose of scenarios is to examine possible uncertainties that might arise in a complex and turbulent environment. By deploying this methodology, a wider view can be taken and more relevant questions can be asked. This approach encourages a holistic examination of the system and exposes the complex interactions that might impact it. By thinking the unthinkable, and questioning structures that are ordinarily taken as a given, it is possible to better anticipate and adapt to future changes. [...] Traditionally, the world of patents has been viewed through the familiar lens of the grey Market Rules scenario. However, the scenario process demonstrates that it is unwise not to take a much wider perspective into account: the other three scenarios reveal further dimensions often overlooked by the IP system. (11).

This scenario process was a laudable initiative from an RRI perspective. According to Elahi and Ramirez $[39$, p. 205], quoting a key EPO official, '[t]he scenarios themselves appeared in countless (external) publications on IP and the so-called "IP5" coalition of five leading patenting offices (EPO, USPTO, the Japanese, Korean, and Chinese patenting offices). Moreover, the scenarios were embraced by Pompidou's successor, Alison Brimelow, who gave them wider internal as well as external distribution'. This appears to indicate a robust willingness to be reflexive at the institutional level, at least until Brimelow resigned in 2010.

It is currently difficult to document the internal value reflection in the top management of EPO, and as a part of the culture in EPO generally. However, some aspects of the EPO seem to be counterproductive for such reflection. One aspect is that the staff at EPO generally consists of people with scientific or engineering background. ${ }^{37}$ This homogeneity in backgrounds may restrict broad deliberation on values and assumptions unless such deliberation is encouraged in the

\footnotetext{
37 https://www.epo.org/about-us/jobs/examiners/profile.html [Accessed April 2019]
}

organisation. Parthasarathy and Walker [31, p. 337] show that there was indeed such encouragement during the 1990s and early 2000s. However, there is evidence that the culture has changed to the disadvantage of reflexivity. According to SUEPO (in 2009, referring to several staff studies), the organisational climate has deteriorated since: 'All studies found that the present "command and control" style of management is not appropriate for the EPO and conclude that a change is needed towards a more values-based management. The studies propose delegation of authority and "management-by-learning" or "management-by-objectives" as opposed to the current "management-by-instructions" style.' [32]. Our observations in "Engagement with stakeholders at the institutional level" clearly show that such a change in management style has not occurred.

Another sign of a current lack of willingness to engage in value-based reflection was a high-level EPO ban on attendance of their staff at a workshop on responsiveness in European patenting practices, including a broad range of prominent experts and stakeholders in ethics and patenting, organised as part of the Patent Ethics project, in Munich in 2016. Such withdrawing from open discussion indicates a closed culture in the EPO.

The recent draft Strategic Plan (April 2019) to some extent reflects on (the importance of) values, but here also, the reflection is of a closed nature and limited to EPO corporate values (regarding integrity, respect, and fairness). Referring to interviews with senior UK science policy actors, Macnaghten and Chilvers [40, p. 541] report that 'closed cultures were seen to create an ethical distance between scientists and societal interests and to lead to the normalisation of ethically sensitive activities' ${ }^{38}$ This observation about scientific cultures seems relevant also in the EPO context.

Though informative, we cannot draw strong conclusions from these indications that broad organisational reflexivity on values, uncertainties and assumptions does not exist in the EPO. More research is thus needed on this aspect.

\section{Reflexivity at the Patent Processing Level}

With regard to the granting of patents, the mandate of the EPO is to apply the articles of the EPC as neutrally and objectively as possible. There should be no open deliberation on assumptions in patent legislation or EPO

\footnotetext{
$\overline{38}$ It should be noted that the respondents believed that scientific cultures and practices in fact had become more open.
} 
guidelines, but simple application with high predictability; otherwise, there will be time-consuming opposition and appeals. Even though scholars inspired by science and technoloyg studies (STS) would be quick to point out that this examination and decision-making process is valueladen (see for instance Sideri [41]), such an insight should not be allowed to influence examiners' processing of concrete applications.

However, for ethically sensitive patent applications, the EPO has initiated a system of labelling so-called sensitive cases (SeCa) [31]. These are cases that might invoke controversy in society and that therefore need to be scrutinised with extra diligence. The EPO official interviewed in this project stated: 'There is a network of specialized colleagues dealing with $\mathrm{SeCa}$ cases. There is lots of internal consultation and there is an active discussion culture on this. ${ }^{39}$ Parthasarathy [42, p. 112] reports that this extra scrutiny is carried out with internal legal expertise, representatives of the public relations division and higher level management. The mechanism seems to be a matter of risk management by the EPO, rather than a way to open up the discussion with society. A similar point was made earlier by Schneider [12, p. 626] who criticised the lack of involvement in this procedure of people from a wide range of (disciplinary) backgrounds. Moreover, $\mathrm{SeCa}$ cases are just a few cases out of thousands of decisions taken every year in the biotechnology field of the EPO, during the search, examination, opposition and appeal phases. ${ }^{40}$ Most of the decisions made on biotechnology patents (or patents in other technology fields) are not subject to such broader discussion in the EPO.

In RRI, it is also important to be aware and reflexive about scientific uncertainty and ambiguity [19]. The scientific uncertainties of emerging science and technologies are an important reason for the need for responsibility in the first place. Some claim that scientific uncertainties are indeed irreducible in many emerging fields [43]; however, for the EPO, reducing uncertainty is considered a core activity: 'We deal with uncertainty as our daily business; it's the nature of our job. Our job is to create certainty through examination of the patent application. ${ }^{41}$ Scientific uncertainties in patenting

\footnotetext{
$\overline{39}$ Telephone interview carried out on April 27, 2016.

${ }^{40}$ According to EPO statistics, they received 6742 patent applications in the field of biotechnology in 2018. A total of 3637 patents in biotechnology were granted the same year. According to the interview with the EPO official quoted less than one-third of the patent applications in biotechnology is granted.

${ }^{41}$ Telephone interview carried out on April 27th 2016.
}

applications are thus regarded as in principle unproblematic.

The main place for discussion of assumptions and value issues in the EPO is probably in the appeal boards. Here, more principled questions about the interpretation of the EPC are discussed with the parties involved (the patent proprietor and the appellant). Sterckx and Cockbain [37, pp. 243, 297] highlight the WARF appeal case (G2/06 Use of embryos/WARF) as an important example of deliberation about the interpretation of the article on ordre public and morality (article 53(a) EPC). They also mention the G2/07 (Broccoli/PLANT BIOSCIENCE) and G2/08 (Dosage regime/ABBOTT RESPIRATORY) as examples of appeal cases where there has been a willingness to take seriously the value-based restrictions in European patent law. They give the credit for these decisions to the wise leadership of Peter Messerli [37, pp. ix and 322]. ${ }^{42}$

The situation appears to have changed after Messerli retired, as there has recently been a lot of controversy about changes in the organisation of the Boards of Appeal. As Smyth [44] presents it: 'The wider world only noticed the increasingly troubled situation at the EPO when a member of the Boards of Appeal of the EPO was suspended by the President without the prior sanction of the AC, an action that appeared to compromise the judicial independence of the Boards of Appeal. This occurred shortly after a seminal decision of the Enlarged Board of Appeal (EBA), which upheld an objection of suspicion of partiality against its Chairman, on the sole basis of his dual administrative role within the management of the Office. The response of the President, transferring some administrative powers from the EBA Chairman to himself, seemed to make the problem worse rather than better.' Smyth refers to the events that started with the decision in April 2014 (R19/ 12) of the Enlarged Board of Appeal to recuse the VicePresident of the EPO from a Petition for Review case. In the set-up of the European Patent Organisation, the judiciary branch (the Boards of Appeal) is part of the EPO and does not have its own legal status. One of the vice-presidents (Vice-President DG3) used to be both the chair of the Enlarged Board of Appeal and the person within EPO senior management that ran the Boards of Appeal, which has raised questions related to the independence of these boards (laid down in article

\footnotetext{
${ }^{42}$ Messerli was Vice-President of EPO and Head of the Boards of Appeal from 1996 to 2011.
} 
23 EPC). This was reinforced by the fact that some of the individual labour conflicts discussed in "Engagement with stakeholders at the institutional level" involved Board of Appeal members. In March 2015, the EPO President recommended to the AC the creation of a new position, President of the Boards of Appeal, specifically in charge of managerial and organizational tasks relating to the Boards of Appeal Unit, delegated directly by and under the hierarchical control of the EPO President. The Boards of Appeal President would no longer be member of the EPO team of vice-presidents but would still be chair of the Enlarged Board of Appeal. After consultations, in June 2016, the AC decided to go ahead with this reform (and with the double role of the new President of the Boards of Appeal as manager and as judiciary), but with the President of the Boards of Appeal being responsible to the $\mathrm{AC}$, and hierarchically independent from the EPO President. ${ }^{43}$ This means for example that the President of the Boards of Appeal is in charge of appointment of members of these boards, and not - as previously - the EPO President. The Association of the Members of the Boards of Appeal (AMBA) has been and still seems to be critical of the reform, questioning whether the delegation will really prevent intervention from the part of the EPO President. ${ }^{44}$

Again, the evidence provided here is not sufficient for drawing strong conclusions on the reflexivity within the EPO, but suggests that such reflexivity is not deeply embedded in the organisation and that there are counterincentives. More studies of the EPO should be conducted to shed light on its organisational culture and working practices. $^{45}$

Responding and Adapting to the Input and Deliberations

The responsiveness dimension of RRI highlights the fact that it is not sufficient to simply organise a stakeholder meeting, to make scenarios or to hold a Social Conference. These actions may well be window dressing if the organisation is not committed to learn from them. Responsiveness involves the openness for discussing topics that stakeholders deem important, it implies the willingness to change and adapt, and it goes

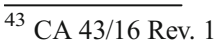

${ }^{44}$ See http://www.amba-epo.org/ [Accessed April 2019].

${ }^{45}$ An interesting but relatively old (2006) study of working practices and staff incentives in the EPO can be found in a report by the Institut d'Economie Industrielle (IDEI) [45].
}

beyond mere strategic reaction to events in the organisation's environment (see also [21]). Related to the topics addressed under the three first dimensions above, we can add some reflections on responsiveness.

With regard to the political level, we can note that there has been certain responsiveness in the European Patent Organisation towards the European Union, as the provisions on patenting in the Biotech Directive were incorporated into the EPC, although this was not legally required by the EPC. The then president of the EPO also responded quickly to the Brüstle decision in the European Court of Justice (ECJ), interpreting Article 6 (2) (c) of the Biotech Directive (denying the patentability of the use of human embryos for industrial and commercial purposes) and promised that it (and similar ECJ decisions) would influence future decisions in the EPO. $^{46}$

From the information reported by Elahi and Ramirez [39, p. 205], the EPO also appears to have been extremely responsive related to the EPO Scenarios project: According to one EPO official interviewed for their study, the Scenarios project encouraged EPO senior officials to address issues such as "global patent warming" (i.e. the surge of patent applications creating a great backlog). Further, it helped the EPO to establish institutional links with the World Economic Forum (WEF), the Organisation for Economic Cooperation and Development (OECD) and the United Nations (for green technology). It was instrumental in EPO's strategical renewal and in revising its mission statement. The scenario planning effort of the EPO is credited as having supported the coming about of two major institutional innovations: (1) the London Protocol, an optional agreement aiming at reducing the costs relating to the translation of European patents, and (2) the so-called Unitary Patent. As far as the working processes of the EPO are concerned, it enabled the introduction of an internal Raising the Bar program to reduce the number of trivial patents clogging the IP system. It is also credited for accelerating the introduction of an end-to-end digitization program to produce patenting with zero paper emission. If all this is indeed the case, these are impressive results from a scenario process in terms of

\footnotetext{
$\overline{46}$ http://blog.epo.org/patents/patents-and-biotechnology-\%E2\%80 \%93-latest-developments/ [Accessed August 2017]
} 
learning and institutional development. However, there is a lack of evidence on whether this has influenced the ability of EPO staff to engage in more reflexive deliberation on values and assumptions at the patent examination level. From an RRI perspective, this is of greater interest than the impact the scenarios have had on EPO's business strategies.

With regard to responsiveness towards stakeholders, we have seen that the EPO, in its design, is responsive primarily to patent applicants, patent attorneys and delegations from national patent offices. With regard to involvement of other stakeholders at the level of examining and granting patents, the possibility for third-party observations and the amicus curiae hearing related to the WARF case may be regarded as positive examples, but there is a need for systematic follow-up research on how the EPO responds to such input from non-industrial NGOs and citizens generally.

At the level of examination and granting of patents, the system is in principle designed against responsiveness to society. Because EPO's mandate is to apply the $\mathrm{EPC}$, no arguments are allowed to influence granting decisions except those that directly concern the existence of prior art and the interpretation of the legal texts (including case law). Patent examiners should in principle not be influenced by public or stakeholder opinion in their interpretation of how the patentability requirements (novelty, inventive step, industrial use) apply to a case. Whether they in practice are immune to such influences would be an important empirical study.

These considerations indicate that the responsiveness to society of the EPO needs much more scrutiny. This indication was also clearly confirmed by the participants in a workshop on responsiveness in European patenting practices organised in Munich, May 2016. ${ }^{47}$

\section{How Can the EPO Align Better with RRI Principles?}

We have seen that the dimensions of RRI do not have a strong position in the EPO, neither at the institutional level nor at the level of patenting practices. The next question is then how the EPO can be made more responsive to RRI-related concerns. We focus on three main dimensions: (a) changes of legislation, (b) changes of EPO practices within the current legal framework, and (c) changes in governance.

\footnotetext{
$\overline{47}$ https://responsivepatenting.wordpress.com/ [Accessed April 2019].
}

Legislation

Formally, patent law can only be changed with the approval of the contracting states of the EPC and thus through the political mandate of the national delegations to the AC or the diplomatic conferences of the EPC. It would take targeted political action in member states of the EPC to revise the EPC in such a way that it is more inclusive to ethical and societal considerations. Such revisions could entail less extensive patent rights, new categories of exceptions to patentability or even new requirements (beyond novelty, inventive step and industrial applicability) that explicitly deal with the social impact of the invention at hand. Concerted and targeted political action is hindered by the fact that this policy field is technical and hard to understand and communicate (both for the public, the media and politicians). It involves powerful international organisations that are regarded as hard to influence by individual countries (at least smaller ones). Moreover, the possible impacts of action versus non-action may not be clear to politicians or the public.

One might also point to the fact that the EPO operates in a global framework (most importantly the Agreement on Trade-Related Aspects of Intellectual Property Rights (TRIPS) under the auspices of the World Trade Organisation), which is often perceived to limit the room for political action by the EPC member states. On the level of material patent law, it has however been shown that there is indeed room within the current broader global and European legal patent framework for making national and regional adaptations [46]. Lamping et al. [47] convincingly argue this in relation to the TRIPS framework in the 2014 Declaration on Patent Protection-Regulatory Sovereignty under TRIPS. $^{48}$

Moreover, given the high level of overlap between EPC and EU membership, it would also be possible to influence European patent law via EU legislation, with the 'voluntary' inclusion of the European Biotech Directive into the EPC as an earlier example of how the EPO can be responsive. This also makes sense given the EU patent package that has established the EU Unitary Patent and the Unified Patent Court (and that will come into force after sufficient ratification). Additionally, as EU legislation involves the European Parliament, this would also add to the democratic legitimacy of the

\footnotetext{
$\overline{{ }^{48} \text { See also [46]. }}$
} 
patent system. Proper coordination between the EPC part of the European patent system and the EU part is however essential to avoid legal disharmony [48].

\section{Changes Within the Current Legal Framework}

Even if the formal legal system is a 'hard' framework around the EPO, the 'soft' room for manoeuvre of the EPO should not be neglected. The EPO can itself make rules and guidelines that do not require full ratification within the EPC. It is also the case that not all alignment to RRI, for instance broader external stakeholder involvement, would require great changes in the EPO. In the pre-granting phase, a better use can be made of thirdparty observations, for example by inviting such observations (as is done by amicus curiae briefs in the opposition phase) for patent applications that are perceived as being especially socially relevant, and by following up on them. This would require upgrading and broadening of the current $\mathrm{SeCa}$ procedure, through involvement of external experts from other disciplines (such as ethics, economics and science and technology studies), aiming at opening specific dialogue processes. Such processes run two ways. On one hand, they provide input regarding potential ethical and social implications of inventions, and on the other hand, they provide input for the broader science and policy community on new developments in technology, and to policy makers on possible regulatory gaps. In that sense, patent applications can function as an early warning system in the governance of technology.

The EPO could also follow up on peer-to-patent (P2P) pilots as have been run by the USPTO and the Australian Patent Office. Although P2P essentially is about improving patent quality by opening up the patent examination process to the public (with an eye to better and more rapidly establishing prior art), and not about inclusion of a broader range of ethical and social considerations regarding patent applications, it would signal openness. Tellingly, what the EPO currently does in terms of collaborative search and examination is within the framework of the IP5 (through cooperation between examiners of the five largest patent offices worldwide), i.e. within the patent system, without any outreach.

Another option is to increase the internal competences of the EPO, by establishing relevant multidisciplinary and diverse expertise within the organisation itself, to assist both EPO management and examiners, and to broaden their horizon. Such a support function does not necessarily have to involve setting up procedures for mandatory involvement of such expertise in the patenting process (like internal ethics boards). The core issue here is to strengthen the analytical and reflexive competencies within EPO regarding the potential broader impacts of patents, in light of developments in technology and society.

Linked to the issue of expertise is the enhancement of transparency. Many have referred to the EPO as being a 'black box'; we know what goes in (applications), we know what comes out (patents), but that is it. If we look at the information provided by the EPO in its annual reports and on its website, it is all about this process: how many applications, who are the largest applicants, how many patents have been granted and in which fields is the process timely, et cetera. There is no information at all about key developments in technology, about the societal impact of patents, or the content of decisions on patenting. In this context, the patent databases that the EPO uses are not designed to extract meaningful information. A simple query like how many patent applications are turned down in the examination and granting phase because of non-patentability due to the ordre public and morality clause of article 53(a) is impossible to make using the current EPO Register, because the grounds for refusal (and more generally the legal provisions involved) are not included in the record fields. Only decisions of the Board of Appeals can be searched in that way. More generally, the EPO Register and EPO's Espacenet are archaic and user-unfriendly databases. Commercial providers offer better search tools, but these are not cheap. This may look like a minor issue, but the signal that comes from this practice is that patents involve private interests only (and patent information is something that has to be bought), rather than patent granting being seen as the exercise of a public authority, which should be transparent and open.

Perhaps the challenges to the alignment to RRI are largely a matter of organisational culture. This culture is currently influenced by the great backlog of patent applications, so an important organisational focus of the EPO (and many national patent offices, and other patent offices worldwide) is on increasing productivity [49, p. 31]. Other goals, such as strengthening responsiveness in an RRI perspective, would have to compete with this focus. Stilgoe et al. [19] identify the following mediating factors for institutional responsiveness: 'a deliberative science policy culture, emphasising reflexive learning and responsiveness; an open organisational 
culture, emphasising innovation, creativity, interdisciplinarity, experimentation and risk taking; top-level leadership and commitment to public engagement and to taking account of the public interest; and commitments to openness and transparency (Macnaghten and Chilvers, forthcoming). Responsiveness is therefore linked to reflexive capacity'. Of course, these are ideal characteristics of science policy organisations such as research councils and cannot be directly translated to a patent office, but it is possible to take steps in this direction, also for the EPO, if organisational attention was devoted to such responsiveness.

\section{Governance}

As argued above, it appears that currently, there are inadequate governance structures for political control. Drahos [11, p. 24] claims that "patent offices have emerged out of decades of public sector reform as client-oriented, corporately managed and relatively autonomous agencies'. In the case of the EPO, the president of the EPO actively participates in AC meetings, and most proposals for institutional changes go from the EPO President to the AC, after consulting with users. If there is to be increased responsiveness to society in the EPO, there should be a reconfiguration of the division of responsibilities between the $\mathrm{AC}$ and the EPO, in such a way that the $\mathrm{AC}$ is the political body and the EPO is the executive body. In fact, the current informal governance system (including the advisory committees with user representation) may be as important a barrier towards public responsiveness as the formal system, but a barrier that can perhaps more easily be built down. Here, there is no need for EPC changes; in essence, the provisions of the EPC provide such a division of responsibilities. For example, the European Patent Organisation had an external Audit Committee (made up of independent external experts), which was established in 2009, but terminated in 2011 for 'reasons of efficiency'. It was primarily meant to empower the Board of the $\mathrm{AC}$ to better control the Office. Reinstatement of this committee would be a simple step.

We are then back to the point about the need for increased political attention to the patent system. Most importantly, there is a need for the AC to be made up of political representatives rather than representatives from national patent offices. Such a governance structure is common in most other international organizations and the framework and provisions of the current EPC fully allow for that. In such a situation, it would be possible for the AC to instruct the EPO to use their significant room for manoeuvre in the direction of increased responsiveness to society.

\section{Concluding Reflections}

We argued in the introduction for studying the European patent organisation in order to scrutinise the role of intellectual property regimes in RRI. We proceeded to apply four RRI principles to the policies and practices of this organisation. We do not expect that having chosen for instance von Schomberg's definition or Owen et al.'s approach would have changed much in the analysis. Just as when the Wickson and Forsberg analytic framework was applied to standardisation [25] and assessment practices [50], we find that it has been productive in illustrating challenges in the patent system relevant to the overall goal of responsibility in science and innovation.

Our conclusion is that the RRI dimensions are not well implemented in the organisation. Is this because there is something wrong with expecting such an institution to address societal needs and challenges, engage with a range of stakeholders, anticipate and reflect on values and impacts of its decisions and respond to societal concerns? Seen from a political science perspective, the EPO is, like other societal institutions, set up to have a societal function. If we expect institutions like research funders or universities to adapt to new expectations of responsibility, an explicit argument must be provided why some institutions should be decoupled from such expectations. Naturally, institutions will adapt to RRI expectations in different ways, related to their function and context. The suggestions we have included here are thus tailored to the function and context of a patent office.

In the RRI discourse, there is a tendency to emphasize the responsibilities of researchers and innovators, and to regard the design and workings of institutions like the patent system as political questions, and thus outside the scope of RRI. In our opinion, political questions do have a central place in RRI (see also Owen et al. [51], p. 755). Firstly, because the shaping of a new relationship between science and society in the interest of solving our times' grand challenges is a deeply political question. Secondly, researchers and innovators operate in a world shaped by larger incentives and institutions that are politically mandated. When these 
institutions are not designed in terms of RRI principles, we cannot simply transfer this responsibility to the researchers and innovators themselves, even though many of them take that responsibility seriously, also regarding intellectual property rights. However, RRI also involves identifying the appropriate distribution of responsibilities, such as the responsibilities of our politicians to provide for institutions that are conducive to social responsibility of research and innovation. Enhancement of patent law with provisions that enable societal concerns to be better integrated is primarily and ultimately the responsibility of democratically elected politicians, as is safeguarding proper governance structures and practices within an international organisation as the European Patent Organization. However, as RRI scholars, we have also a responsibility to draw scholarly and public attention to such issues, in order to create a pressure on our politicians to act.

In RRI, we thus need to address all institutions in society that are connected to our science and innovation systems, such as patenting. Even if embedded in larger (sometimes global) structures-such as the TRIPS agreement when it comes to patenting - such institutions can be redesigned or adjusted to better help research and innovation serve social goals and align with values in society. Withdrawing from confronting such larger, political questions increases the risk that RRI will lack any potency for real impact.

Acknowledgements This work has been funded by the Research Council of Norway's ELSA program, grant no 220609/ O70. We are grateful for all the discussions we have had with our good colleagues in the Patent Ethics project and for the good advice by the anonymous reviewers.

Open Access This article is distributed under the terms of the Creative Commons Attribution 4.0 International License (http:// creativecommons.org/licenses/by/4.0/), which permits unrestricted use, distribution, and reproduction in any medium, provided you give appropriate credit to the original author(s) and the source, provide a link to the Creative Commons license, and indicate if changes were made.

\section{References}

1. Denicolò V, Franzoni LA (2004) The contract theory of patents. Int Rev Law and Econ 23(4):365-380

2. Roin BN (2005) The disclosure function of the patent system (or lack thereof). Harv Law Rev 118(6):2007-2028

3. Merges RP, Nelson RR (1990) On the complex economics of patent scope. Columbia Law Rev 90(4):839-916
4. Gold ER, Kaplan W, Orbinski J, Harland-Logan S, NMarandi S (2009) Are patents impeding medical care and innovation? PLoS Med 7(1):e1000208

5. Hall BH (2007) Patents and patent policy. Oxf Rev Econ Policy 23:568-587

6. Moser P (2013) Patents and innovation: evidence from economic history. J Econ Perspect 27(1):23-44

7. March JG, Olsen JP (2011) The logic of appropriateness. In: Goodin RE (ed) The Oxford handbook of political science. Oxford University Press, Oxford, pp 478-497

8. Forsberg E-M, Braarud Hanssen A, Nielsen HM, Olesen I (2017) Patent ethics: the misalignment of views between the patent system and the wider society. Sci Eng Ethics 24: 1551-1576. https://doi.org/10.1007/s11948-017-9956-5

9. Hettinger N (1995) Patenting life: biotechnology, intellectual property, and environmental ethics. Boston Coll Environ Affairs Law Rev 22(2):267-305

10. Koepsell D (2014) It is not ethical to patent or copyright genes, embryos, or their parts. In: Caplan AL, Arp R (eds) Contemporary Debates in Bioethics. John Wiley \& Sons, Hoboken, pp 25-143

11. Drahos P (2010) The global governance of knowledge. patent offices and their clients. Cambridge University Press, Cambridge and New York

12. Schneider I (2009) Governing the patent system in Europe: the EPO's supranational autonomy and its need for a regulatory perspective. Sci Public Policy 36(8):619-629

13. Fisher E, Mahajan RL, Mitcham C (2012) Midstream modulation of technology: governance from within. Bull Sci Technol Soc 32(6):485-496

14. Lundvall BÅ (1992) National systems of innovation: towards a theory of innovation and interactive learning. Pinter, London

15. Malerba F (2006) Sectoral systems: how and why innovation differs across sectors. In: Fagerberg J, Mowery D, Nelson R (eds) The Oxford handbook of innovation. Oxford University Press, Oxford, pp 380-406

16. Bergek A, Jacobsson S, Carlsson B, Lindmark S, Rickne A (2008) Analyzing the functional dynamics of technological innovation systems: a scheme of analysis. Res Policy 37: 407-429

17. Etzkowitz H, Leydesdorff L (2000) The dynamics of innovation: from national systems and "mode 2 " to a triple helix of university-industry-government relations. Res Policy 29: 109-123

18. Edquist C (2005) Systems of innovation: perspectives and challenges. In: Fagerberg, Jan, Mowery D, Nelson R (eds) The Oxford Handbook of Innovation. Oxford University Press, Oxford, pp 181-208

19. Owen R, Stilgoe J, Macnaghten P, Gorman M, Fisher E, Guston D (2013) A framework for responsible innovation. In: Responsible innovation: Managing the responsible innovation of science and innovation in society. John Wiley, London, pp 27-50

20. Kearnes M, Rip A (2009) The emerging governance landscape of nanotechnology. In: Gammel S, Lösch A, Nordmann A (eds) Jenseits von Regulierung: Zum politischen Umgang mit der Nanotechnologie. Akademische Verlagsgesellschaft, Berlin, pp 97-121

21. Pellizzoni L (2004) Responsibility and environmental governance. Environmental Politics 13:541-565 
22. Van Overwalle G (ed) (2009) Gene patents and collaborative licensing models. Cambridge University Press, Cambridge

23. Von Schomberg R (2013) A vision of responsible innovation. In: Owen R, Heintz M, Bessant J (eds) Responsible innovation: managing the responsible innovation of science and innovation in society. John Wiley, London, pp 51-74

24. Jacob K, van den Hoven J (2013) Options for strengthening responsible research and innovation: report of the expert group on the state of the art in Europe on responsible research and innovation. Brussels, European Commission

25. Wickson F, Forsberg E-M (2014) Standardising responsibility? The significance of interstitial spaces. Sci Eng Ethics 21: 1159-1180. https://doi.org/10.1007/s11948-014-9602-4

26. UNEP, EPO, ICTSD (2010) Patents and clean energy: bridging the gap between evidence and policy. Final report. http://www.eurosfaire.prd.fr/7pc/doc/1308064085 patents clean_energy_study_en.pdf. Accessed April 2019

27. Crespi RS (1997) Biotechnology patents and morality. Trends Biotechnol 15(4):123-129

28. Witek R (2005) Ethics and patentability in biotechnology. Sci Eng Ethics 11:105-111

29. Schneider I (2014) Exclusions and exceptions to patent eligibility revisited: examining the political functions of the 'Discovery' and 'Ordre Public' clauses in the European Patent Convention and the Arenas of Negotiation. In: de Miguel I, Romeo Casabona C (eds) Synbio and Human Health. A Challenge to the Current IP Framework? Springer, Dordrecht, pp 145-174

30. Borras S (2006) The governance of the European patent system: effective and legitimate? Econ Soc 35(4):594-610

31. Parthasarthy S, Walker A (2014) Observing the patent system in social and political perspective: a case study of Europe. In: Okediji RL, Bagley MA (eds) Patent law in global perspective. Oxford University Press, Oxford

32. SUEPO (2009) Towards a human resource policy for the EPO. CA/180/09. Document to the EPO administrative council

33. Akers NJ (2000) The referencing of prior art documents in European patents and applications. World Patent Inf 22:309315

34. Guellec D, van Pottelsberghe de la Potterie B (2007) The economics of the patent system. IP Policy for Innovation and Competition. Oxford University Press, Oxford

35. Kica E, Rodriquez V, Groenendijk N (2012) High-quality patents for emerging science and technology through external actors. Eur Intellect Prop Rev 4:221-228

36. Kica E, Groenendijk N (2011) The European patent system: dealing with emerging technologies. Innovation: Eur J Soc Sci Res 24(1-2):85-105

37. Sterckx S, Cockbain J (2012) Exclusions from patentability. how far has the European Patent Office Eroded boundaries? Cambridge University Press, Cambridge and New York

38. European Patent Office (2007) Scenarios for the future. https://www.epo.org/service-support/publications. html?pubid=69\#tab3. Accessed April 2019
39. Elahi S, Ramirez R (2016) Appendix E. The European Patent Office case study. In: Ramirez R, Wilkinson A (eds) Strategic reframing. The Oxford scenario planning approach. Oxford University Press, Oxford

40. Macnaghten P, Chilvers J (2014) The future of science governance: publics, policies, practices. Environ Plann C 32:530-548

41. Sideri K (2014) Bioproperty, biomedicine and deliberative governance. Ashgate, Farnham

42. Parthasarthy S (2017) Patent Politics: Life Forms, Markets, and the Public Interest in the United States \& Europe. The University of Chicago Press, Chicago

43. Funtowicz SO, Ravetz JR (1993) Uncertainty, complexity and post-normal science. Environ Toxicol Chem 13(12): 1881-1885

44. Smyth D (2016) Editorial - something is rotten in the state of the EPO. The weblog of the Journal of Intellectual Property Law and Practice, 11: 393: http://jiplp.blogspot.no/2016/08 /editorial-something-is-rotten-in-state.html. Accessed April 2019

45. Merges RP (2011) Justifying intellectual property. Harvard University Press, Cambridge

46. Tvedt MW, Forsberg E-M (2017) The room for ethical considerations in patent law Applied to biotechnology. J World Intellect Prop. https://doi.org/10.1111/jwip.12087

47. Lamping M, Hilty R, Burk DL, Correa CM, Drahos P, Gopalakrishnan NS, Grosse Ruse-Khan H, Kur A, Van Overwalle G, Reichman JH, Ullrich H (2014) Declaration on Patent Protection - Regulatory Sovereignty under TRIPS (September 24, 2014). IIC - International Review of Intellectual Property \& Competition Law, 2014, Vol. 45, Is. 6, pp 679-698. See also Max Planck Institute for Innovation \& Competition Research Paper No. 14-19. Available at SSRN: https://www.mpg.de/8132986/PatentDeclaration.pdf. Accessed April 2019

48. Aerts RJ (2018) The European Commission's notice on directive 98/44 and the European Patent Organization's response: the unpredictable interaction of EU and EPC law. GRUR Int., 7/2018: 721-724

49. Institut d'Economie Industrielle (IDEI) (2006) IDEI report on objectives and incentives at the European Patent Office. http://idei.fr/sites/default/files/medias/doc/by/seabright/report epo.pdf. Accessed April 2019

50. Forsberg EM, Quaglio G, O'Kane H, Karapiperis T, Van Woensel L, Arnaldi S (2015) Assessment of science and technologies: advising for and with responsibility. Technol Soc 42:21-27

51. Owen R, Macnaghten P, Stilgoe J (2012) Responsible research and innovation: from science in society to science for society, with society. Sci Public Policy 39:751-760

Publisher's Note Springer Nature remains neutral with regard to jurisdictional claims in published maps and institutional affiliations. 